\title{
Application of the Fuzzy Method in the Design of Control and Monitoring Systems for Flood Canal Pump Houses
}

\author{
Lukman Medriavin Silalahi*1, Linggar Amnesta Virgian ${ }^{2}$ \\ ${ }^{1,2}$ Program Studi Teknik Elektro, Universitas Mercu Buana \\ E-mail: ${ }^{* 1}$ lukman.medriavin@mercubuana.ac.id ${ }^{2}$ linggar.vir@ outlook.com
}

\begin{abstract}
The purpose of making a prototype of the canal to flood the pump house is namely as a means of ideas that may later be applied to the pump house in Indonesia. At the end of this task will be made protorype flood canal house pump with which it can work according to the speed of the incoming flow and the height of the water in the canal, on hulu there are 1 pump $12 \mathrm{~V}$ which will drain the water into the canal and also waterflow as a tool that can detect the incoming flow. At the pump house there are 3 pump and 1 water level which will work according to the inflow and the height of the channel. Fuzzy Logic is one method of system control can provide decision that resembles the human decision. In the design process of this plant, used a system of development control of the fuzzy logic system using Arduino. It is intended for a design on the plant control system and monitoring of the pump house flood canal. The use of the Speed Controller PWM on the circuit can work well in regulating the pump speed in the work. Pump 1 and pump 2 has a maximum value of the PWM 144 that can remove water $180 \mathrm{ml}$ that works on low currents and are and sodetan have the value of the PWM to 255 that can get water out of $318 \mathrm{ml}$ of working on a heavy flow.
\end{abstract}

Keywords - Arduino, detection system flow, home pump, sensors, water level

\section{INTRODUCTION}

A flood canal is a canal made by humans to control flood disasters due to overflowing of water flows or rivers. In general, a flood canal is part of a river flow with a widening or deepening in certain parts. The purpose of making a flood canal is to divert (partially or completely) the flow from a river to another place. This diversion is part of the overall flood control system. Apart from being used as flood control, flood canals can also function as transportation and trade routes. In the Flood Canal, a pump house is needed which functions as a means of drainage, namely a complementary building which is a building that helps regulate and control the rainwater flow system so that it is safe and easy to pass through the channel.

The role of electronics is as a support tool that utilizes various components into a unified system that is integrated with a data processor containing a program so that it can provide instructions for carrying out work to various tools such as detectors and sensors connected to an electrical source. Waterflow sensor is a sensor that can read the flow of water in a place. This sensor works to read the rotational speed of the rotor which is caused by the speed of water flow.

An increase in water level can occur at any time if the water flow that enters the flood canal is high, if it is not monitored and the flood canal, the excess water discharge will cause water to spill out of the canal which will flood the surrounding area. To minimize these undesirable things, a microcontroller-based data processing method using electronic media is integrated into the monitoring system by utilizing a water level sensor with the fuzzy logic method. 


\section{RESEARCH METHOD}

This research study discusses control using the fuzzy method and on-off control using the automation method. Figure 1 shows the effort in developing an automatic monitoring and control system for flood canal pump houses, namely conducting a literature study as an application of the proposed research method.

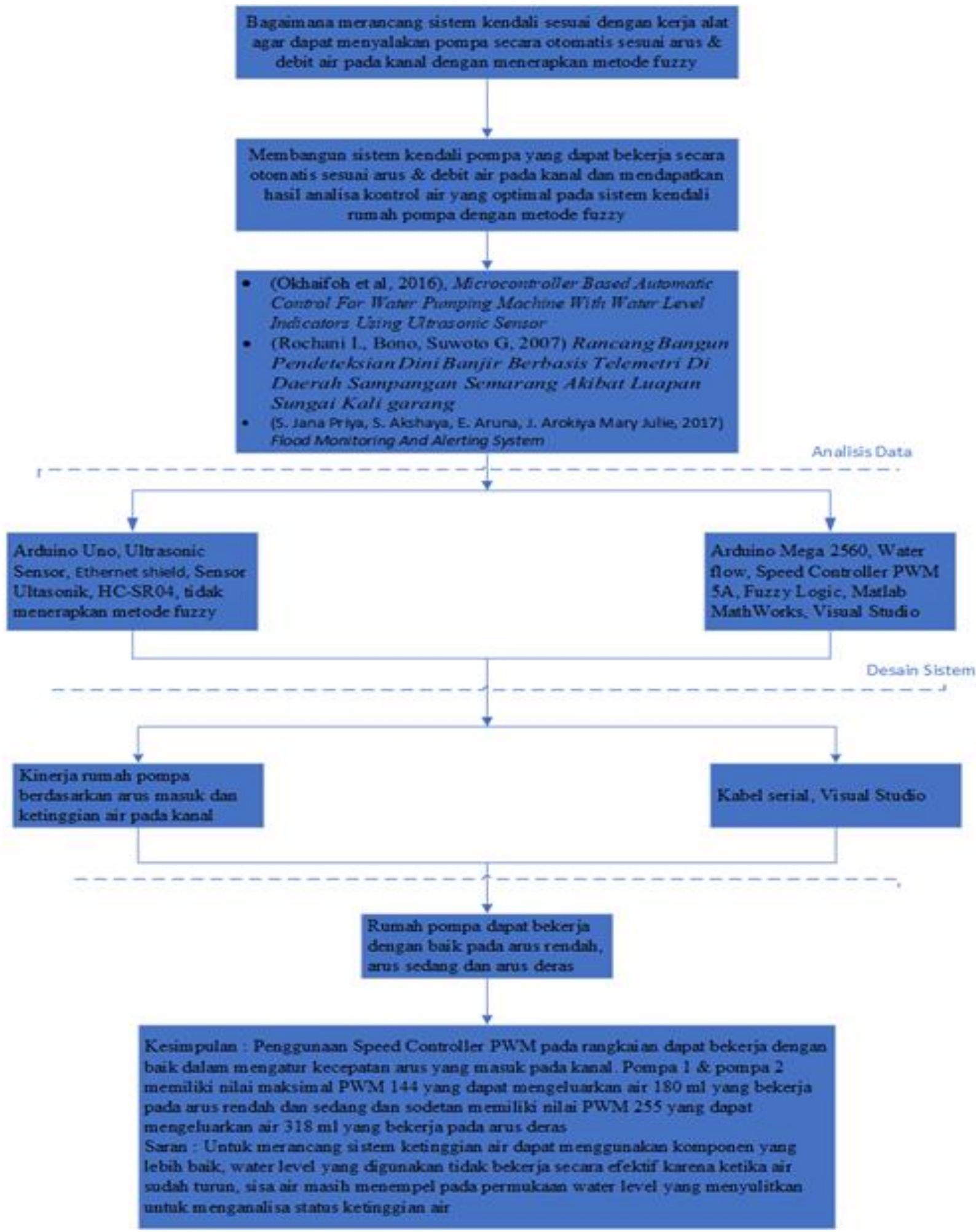

Figure 1. Literature review 
The process for converting non fuzzy variables (numeric variables) into fuzzy variables (linguistic variables). For the fuzzification process, either the crisp input or crisp output variables are divided into one or more fuzzy sets :

\section{Membership Functions of Water Flow Input Variables}

Figure 2 show that the water flow input variable, it is divided into 3 membership groups to find the membership value, the sets are low, medium and heavy. And for membership used in the form of water flow values, namely low (0-180), medium (140-360) and heavy (270500). Following is Figure 3.11 the membership function of water currents.

\section{Membership functions of the Input variable threshold}

Figure 3 show that input variable the threshold is divided into 2 membership sets to find the membership value, the set is normal and dangerous. And for the degree of membership used, namely normal (0) and hazard (1). The following figure 3. threshold membership function.

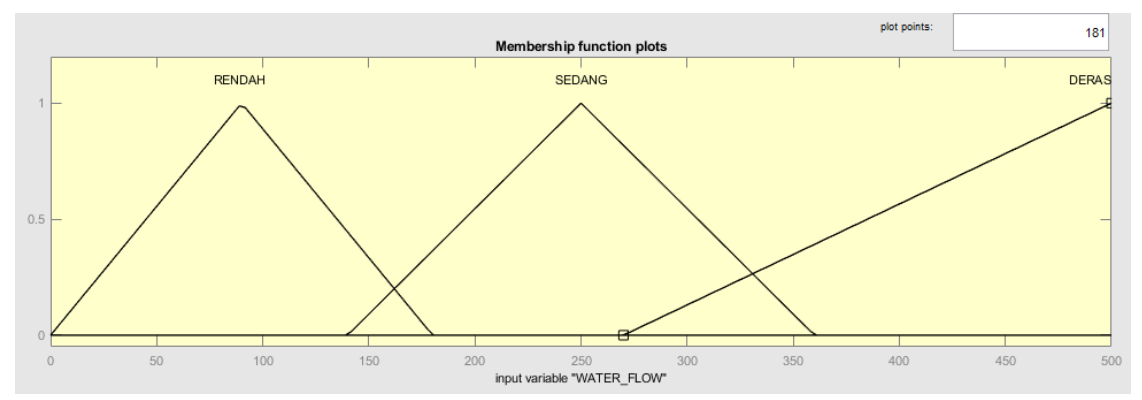

Figure 2. Water Flow Membership Function

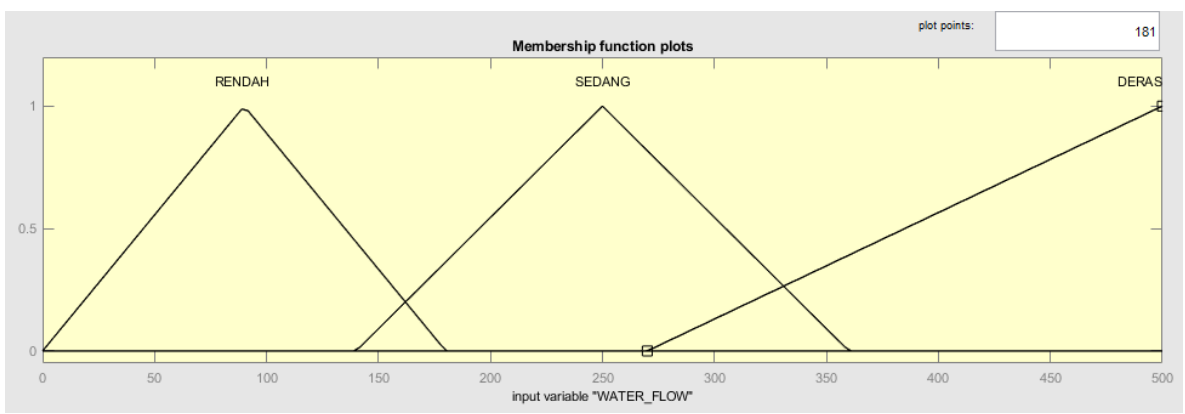

Figure 3. Threshold Membership Function

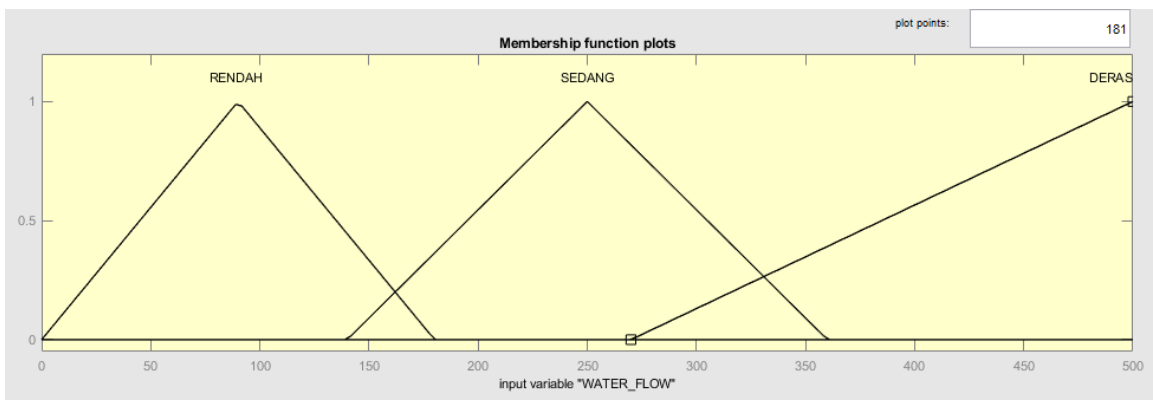

Figure 4. Pump Output Membership Function

\section{Pump Output Variable Membership Functions}

Figure 4 show that the pump output variable is the action of 3 water pumps in the channel, the variable is divided into 4 membership sets to find the membership value, the set is pump 1 from low current level, pump 2 from medium current level and sodetan from heavy current level. The following is a picture of 4 pump output membership functions. 


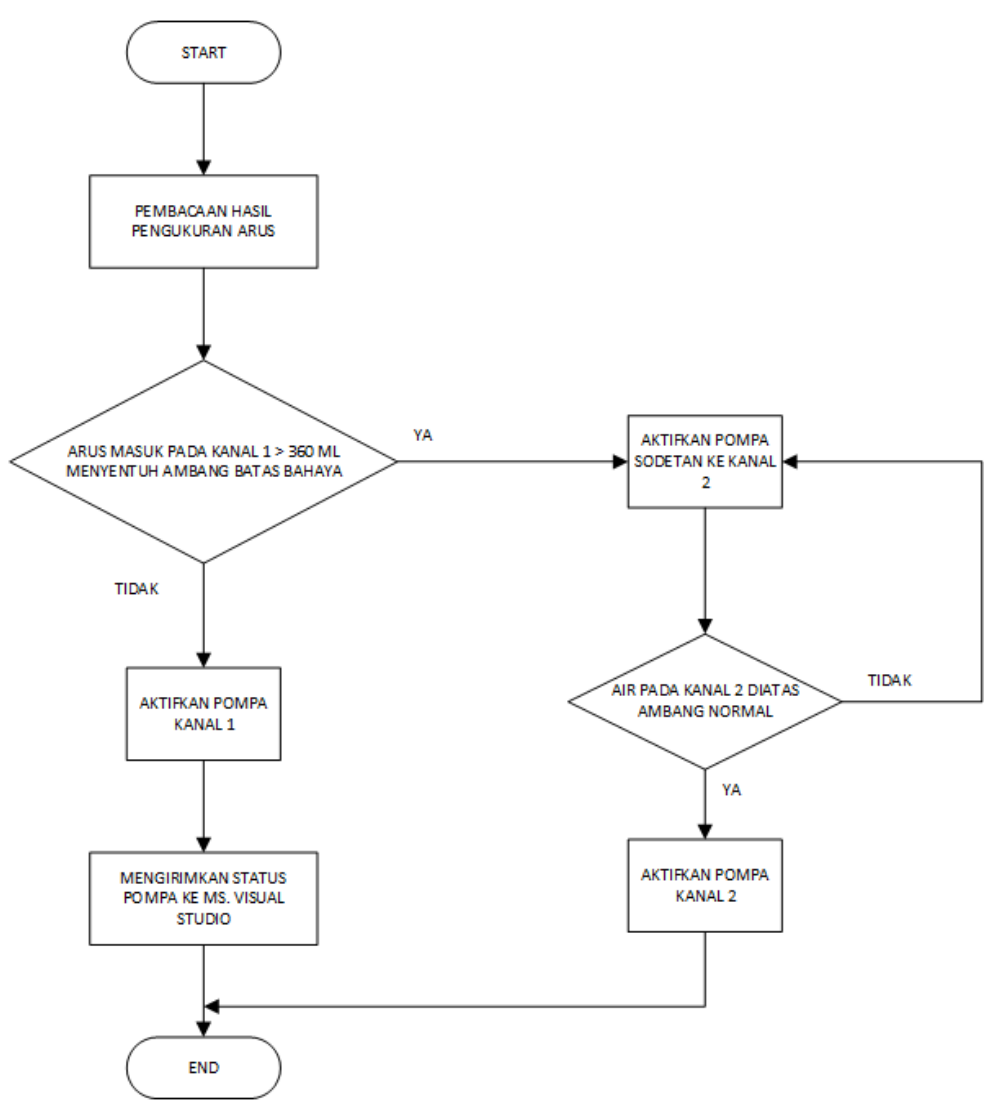

Figure 5. flowchart of Research

Figure 5 shows flowcharts design, to clarify how the workflow design as a whole.

1. The series starts with the input of the power source voltage to turn on the whole series

2. The water will be flowing through the water flow sensor that will read the current speed of incoming containers.

3. The Data read by the sensors water flow will be forwarded to the Arduino to be validated. Then this data will control the pump automatically, if the current entering any alone for not touching the sensor water level then the pump will not turn on.

4. If the water in the canals touch sensor water level then the pump will turn on which will adjust the current on the water flow sensor.

5. The flow of water entering the canal more than $360 \mathrm{ml} / \mathrm{min}$ then it will turn on all the pumps on the channel and also turn on the pump sodetan into the canal 2.

6. The water in the canal 2 touch sensors water level or on the verge of the normal range then it will turn on the pump on channel 2.

\section{RESULTS AND DISCUSSION}

This chapter will discuss the test steps and the results obtained from the application of the Fuzzy Method in the Design of Control and Monitoring Systems for Flood Canal Pump Houses.

The result of designing this tool is an aklirik container with dimensions of $25 \mathrm{~cm}$ x 30 $\mathrm{cm}$ for placing the components used. In this container there are components including the Arduino Mega 2560, 5A PWM Speed Controller, Stepper Motor Driver and also a Power Supply. In the upstream water, there is a $12 \mathrm{v}$ pump to drain water intothe canal container and 
there is also a water flow to measure the speed of the incoming current for and this is shown in Figure 6.

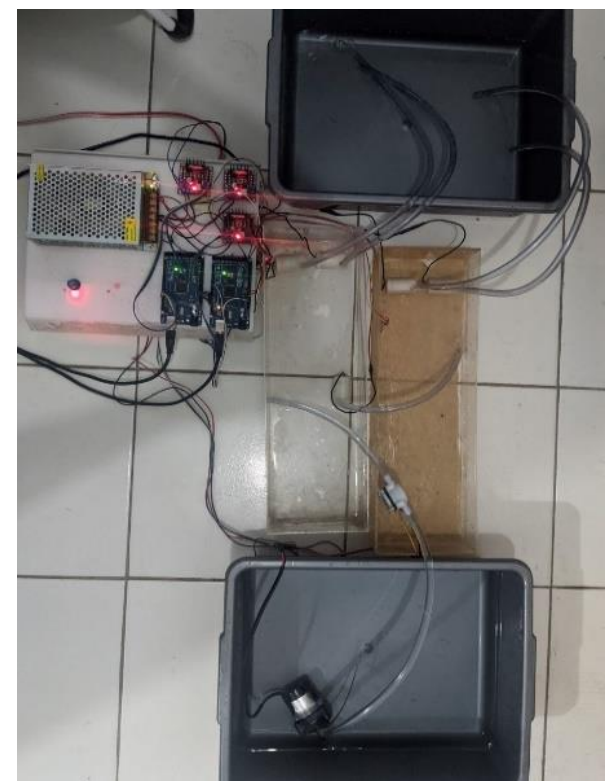

Figure 6. Hardware Design Results

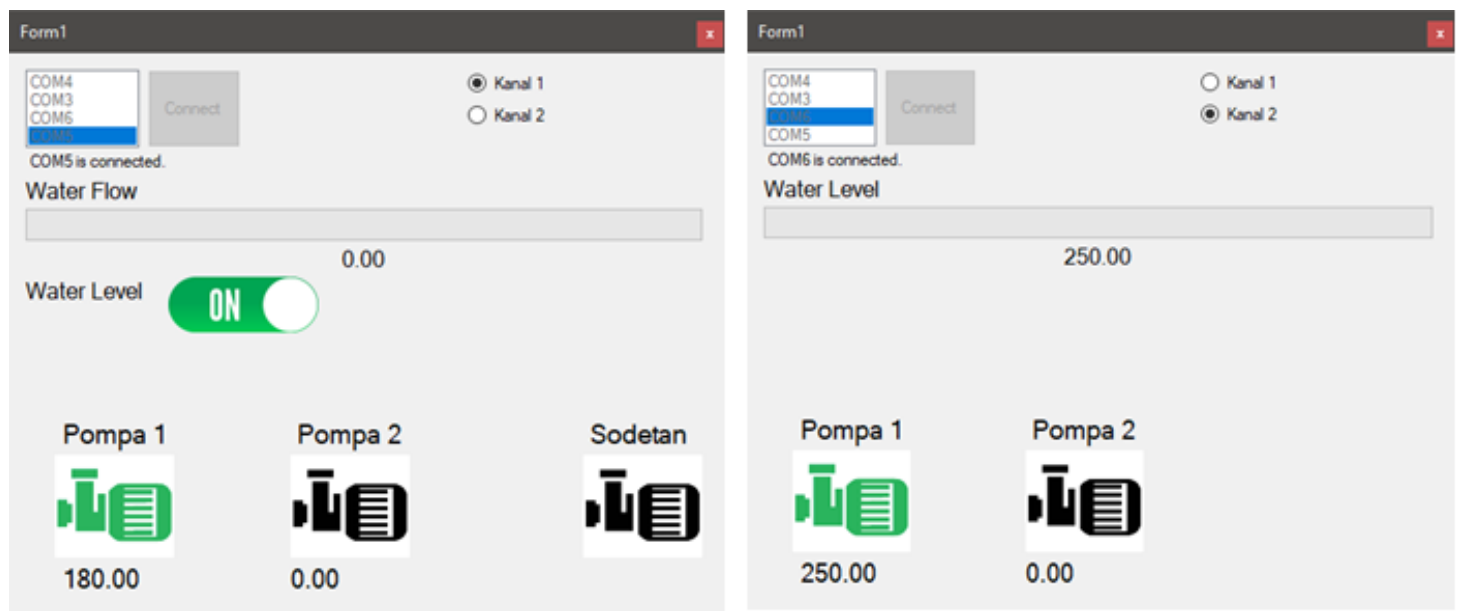

Figure 7. Monitoring Design Result

Figure 7 shows about the tests that have been carried out in 4 conditions in the pump line 1 which will be supplied with a low current of less than $180 \mathrm{ml} /$ minute. The measurement results can be seen in Table 1 .

Table 1. Test results : Low flow

\begin{tabular}{|c|c|c|c|c|c|}
\hline Condition & Flow input (ml) & Pump 1 (ml) & Pump 2 (ml) & Sodetan & Criteria \\
\hline 1 & - & - & - & - & Safe \\
\hline 2 & 138,00 & - & - & - & Safe \\
\hline 1 & 115,00 & 115,00 & - & - & Danger \\
\hline 2 & - & 180,00 & - & - & Danger \\
\hline
\end{tabular}

After testing at low currents can be diliat the results in the table above are obtained analysis here:

1. In the first condition of water flow (inflow) $0 \mathrm{ml}$ and the water level (the threshold) off/safe then all pumps. 
2. On the condition of the to- 2 water flow (inflow) $138 \mathrm{ml}$ and water level (the threshold) is off, all pumps will also be off..

3. On the condition of the to-3 water flow (inflow) $115 \mathrm{ml}$ and water level (the threshold) danger then pump 1 will be active to follow the magnitude of the current in the water flow and pump $2 \&$ sodetan dead.

4. On the condition of the to-4 water flow (inflow) $0 \mathrm{ml}$ and the water level (the threshold) Danger then pump 1 will be active with the full force of $180 \mathrm{ml}$, pump $2 \&$ sodetan off.

In this test, it was carried out with 4 conditions in channel 1 which would be flowed with a moderate current, namely between $140 \mathrm{ml} /$ minute to $360 \mathrm{ml} /$ minute. The results of measurements can be seen in Table 2 .

Table 2. Test results : Medium flow

\begin{tabular}{|c|c|c|c|c|c|}
\hline Condition & Flow input (ml) & Pump 1 (ml) & Pump 2 (ml) & Sodetan & Criteria \\
\hline 1 & - & - & - & - & Safe \\
\hline 2 & 284,33 & - & - & - & Safe \\
\hline 1 & 315,00 & 180,00 & 135,00 & - & Danger \\
\hline 2 & - & 180,00 & - & - & Danger \\
\hline
\end{tabular}

After testing the medium water flow type, the results can be seen in Table 2, the following analysis is obtained:

1. In the first condition of water flow (inflow) $0 \mathrm{ml}$ and the water level (the threshold) is safe then all pumps.

2. On the condition of the to- 2 water flow (inflow) $284 \mathrm{ml}$ but the water level (the threshold) is still in a state OFF/safe then all the pump still off.

3. On the condition of the to-3 water flow (inflow) $315 \mathrm{ml}$ and water level (the threshold) in the state of ON/danger then pump 1 will be active with the full force of $180 \mathrm{ml}$, pump 2 will also be active will be issued a current of $135 \mathrm{ml}$ of the remaining amount of current that can not be taken of the pump 1 and sodetan in the state OFF.

4. On the condition of the to-4 water flow (inflow) $0 \mathrm{ml}$ and water level (threshold) ON/danger then pump 1 will be active with the full force of $180 \mathrm{ml}$, pump $2 \&$ sodetan OFF.

In this test, it is carried out with 4 conditions in channel 1 which will be flowed by heavy currents, namely above $360 \mathrm{ml} /$ minute. The results of measurements can be seen in Table 3.

Table 3. Test results : High flow

\begin{tabular}{|c|c|c|c|c|c|}
\hline Condition & Flow input (ml) & Pump 1 (ml) & Pump 2 (ml)Sodetan & Criteria \\
\hline 1 & - & - & - & - & Safe \\
\hline 2 & 507,00 & - & - & - & Safe \\
\hline 1 & 945,00 & 180,00 & 180,00 & 318 & Danger \\
\hline 2 & - & 180,00 & - & - & Danger \\
\hline
\end{tabular}

After testing the high water flow type, the results can be seen in Table 3, the following analysis is obtained:

1. In the first condition of water flow (inflow) $0 \mathrm{ml}$ and the water level (the threshold) is safe then all pumps.

2. On the condition of the to- 2 water flow (inflow) $284 \mathrm{ml}$ but the water level (the threshold) is still in a state OFF/safe then all the pump still OFF.

3. On the condition of the to- 3 water flow (inflow) $315 \mathrm{ml}$ and water level (the threshold) in the state of $\mathrm{ON} /$ danger then pump 1 will be active with the full force of $180 \mathrm{ml}$, pump 
2 will also be active will be issued a current of $135 \mathrm{ml}$ of the remaining amount of current that can not be taken of the pump 1 and sodetan in the state OFF.

4. On the condition of the to- 4 water flow (inflow) $0 \mathrm{ml}$ and water level (threshold) ON/danger then pump 1 will be active with the full force of $180 \mathrm{ml}$, pump $2 \&$ sodetan OFF.

In the composition of the combination rule for the 3 time trial on the second input provides aggregation action of water flow, which is where the to supply water into the container canal. If the water is already touching the limit of danger then it will give the command to activate the pump at the pump house which will drain the water up to the safe limit (water level off). The experiment will be carried out 3 times, i.e. at low current, medium and heavy. The Output in the fuzzy this is the value of PWM to regulate the speed of the pump to remove the water. Analysis of low flows can be viewed at Figure 8.

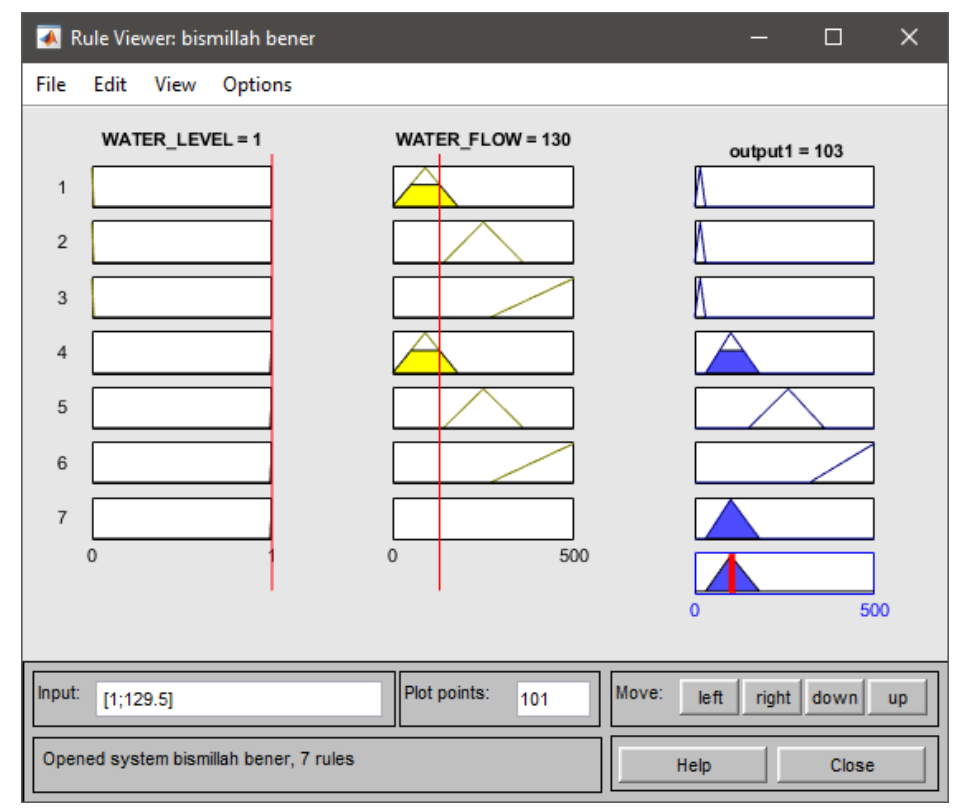

Figure 8. Analysis Matlab Low Current

Experiments on flow low water flow are given a flow of $130 \mathrm{ml}$ and the condition of the water level is active then the PWM output obtained 103

$$
\begin{aligned}
& \text { The Formula Pump } \\
& \begin{aligned}
P & =P W M / \text { factor } \\
P & =103 / 0,8 \\
& =128 \mathrm{ml}
\end{aligned}
\end{aligned}
$$

PWM output on the arduino

$$
\begin{aligned}
& \begin{aligned}
P W M & =W F \\
= & * \text { factor } \\
& =104
\end{aligned} \\
& \begin{aligned}
\text { Difference } & =P W M \text { Matlab } / P W M \text { Arduino } \\
& =103 / 104 \\
& =0,9 \%
\end{aligned}
\end{aligned}
$$


In the experiment, low current output the resulting Matlab to drive the pump of $128 \mathrm{ml}$ with PWM 103. At the output of the arduino PWM generated is 104 which will only turn on pump 1 . On this analysis there is a difference of $0.99 \%$.

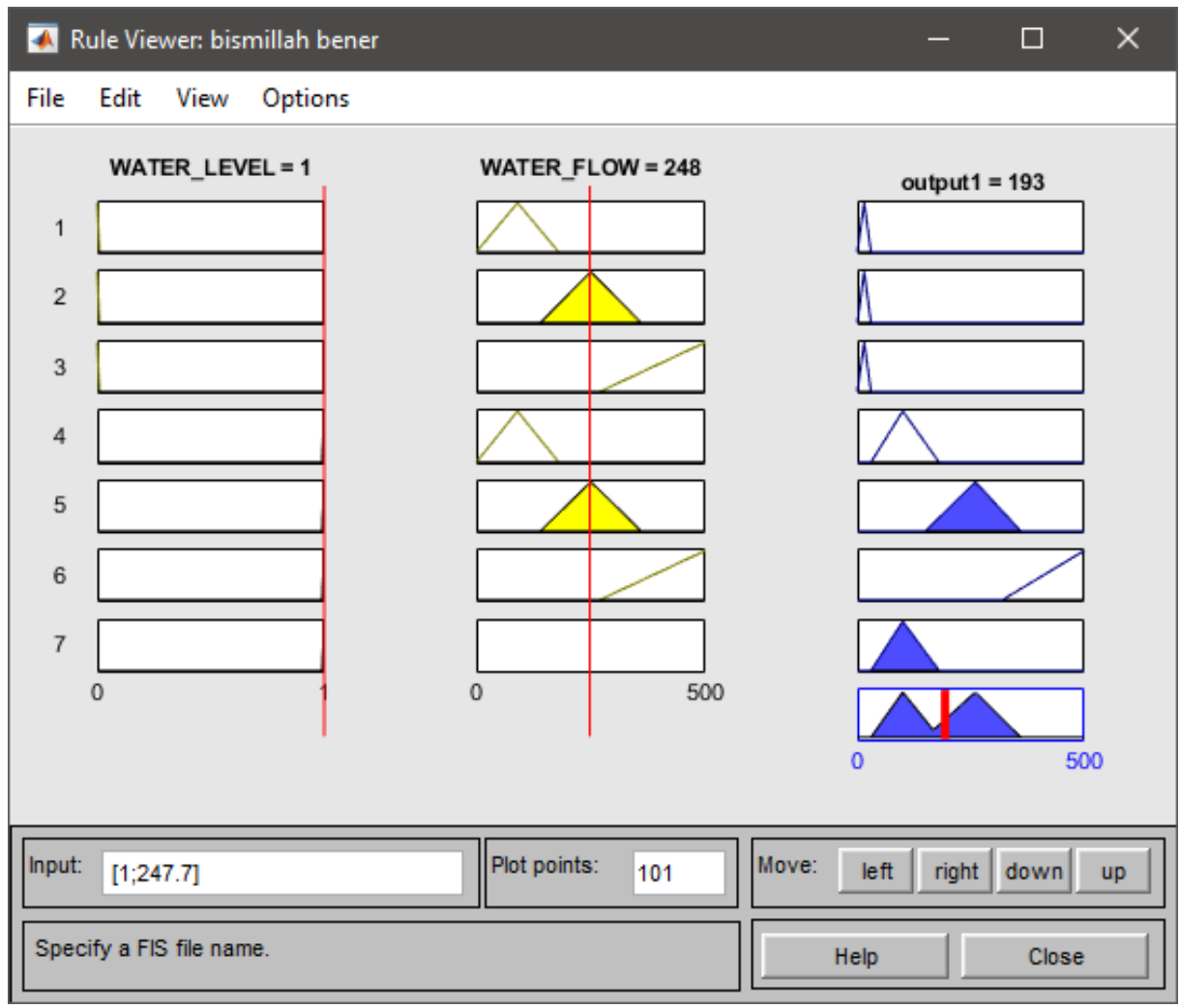

Figure 9. Analysis Matlab Medium Current

The second experiment in Matlab as in figure 9 that the flow is water flow given the current $248 \mathrm{ml}$ and the condition of the water level is active then the PWM output obtained 193.

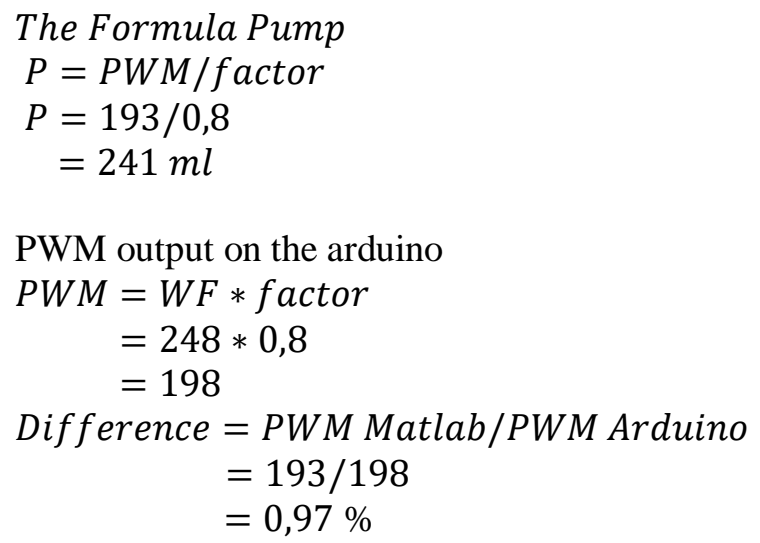

In this experiment the resulting output Matlab to drive the pump amounted to $241 \mathrm{ml}$ with PWM 193. On the total outputs of the arduino PWM generated is 198, in the current are these then the pump 1 and pump 2 are each $99 \mathrm{PWM} /$ pump. On this analysis there is a difference $0,97 \%$ 


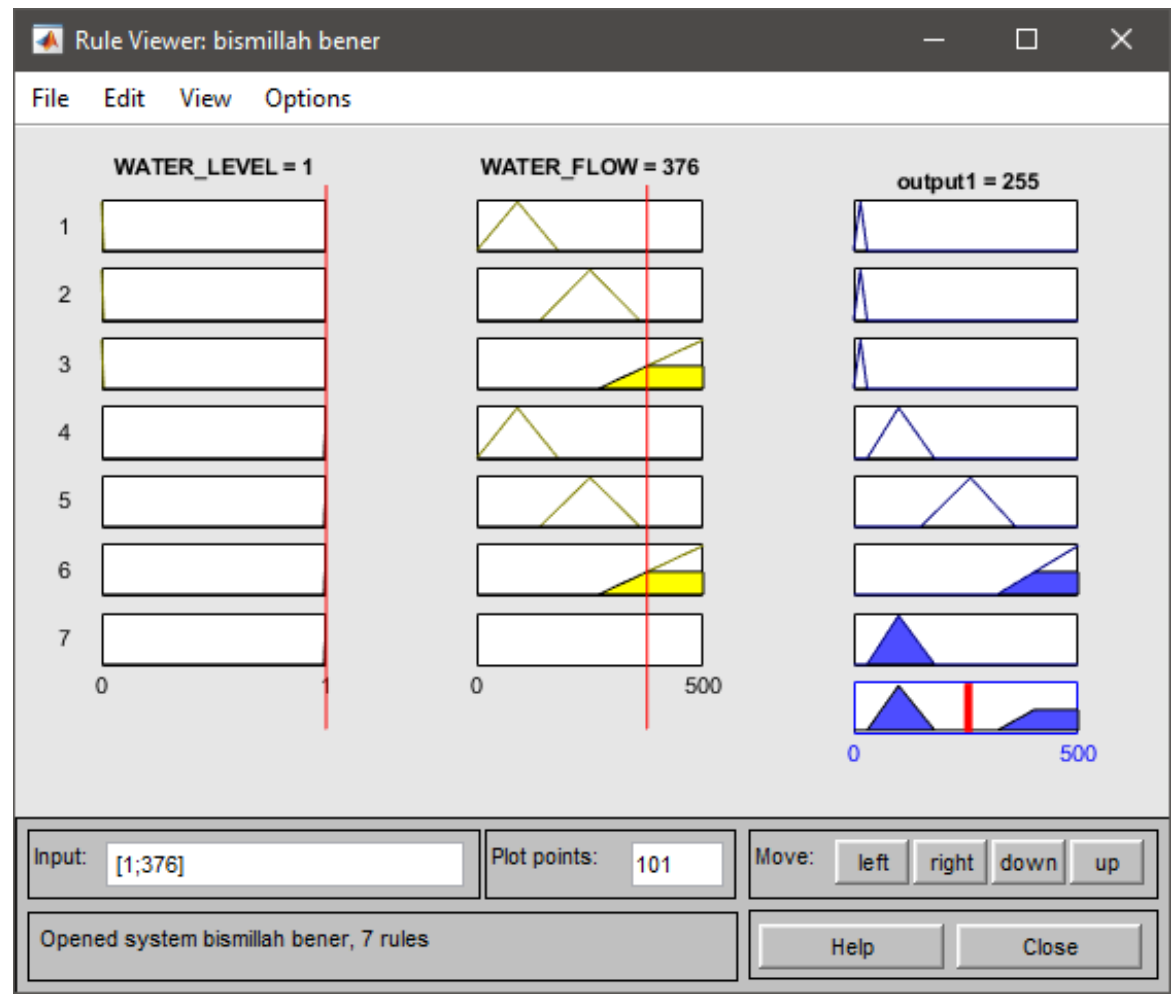

Figure 10. Analysis Matlab High Current

On the third in Matlab can be seen in Figure 10, namely the swift current where the water passes through the water flow above $360 \mathrm{ml}$, then it will issue a PWM to the fullest. For the calculation of the pump 1, pump 2 and sodetan used equations formula. On pump 1 (P1) \& pump 2 (P2) set the maximum PWM 144 produce $180 \mathrm{ml} / \mathrm{min}$ and spatula (S) maximum $\mathrm{PWM}$ of 255 produces $318,9 \mathrm{ml} / \mathrm{sec}$.

$$
\begin{aligned}
& \text { Max } P W M P 1 \& P 2=144 \\
& \text { Max } P W M S=255 \\
& \begin{aligned}
P 1 & \& P 2=P W M / \text { factor } \\
& =144 / 0,8 \\
& =180 \mathrm{ml}
\end{aligned} \\
& \begin{aligned}
S & =P W M / \text { factor } \\
& =255 / 0,8 \\
& =318,8 \mathrm{ml}
\end{aligned}
\end{aligned}
$$

\section{CONCLUSION}

Based on the testing and analysis that has been done, it can be concluded:

1. In monitoring channel status, the MS monitoring system can be used. Visual Studio with serial cable to see the incoming water flow, threshold and also the number of active pumps which can monitor the status of channel $1 \&$ channel 2 in real time.

2. Testing the control system for pump house performance successfully states the normal threshold and the hazard threshold detected at the Water Level and the incoming current including low current, medium current and also heavy current can be adjusted according to the performance of the pump housing.

3. The use of a PWM Speed Controller in the circuit can work well in regulating the speed of the incoming current in the channel. Pump $1 \&$ pump 2 have a maximum 
PWM value of 144 which can discharge $180 \mathrm{ml}$ of water which works at low and medium currents and the sodetan has a PWM value of 255 which can discharge $318 \mathrm{ml}$ of water which works on heavy currents.

4. For the calculation of the fuzzy calculations in the system based on the Matlab calculation and Arduino program calculations there is a difference of $0.9 \%$.

\section{SUGGESTED}

Based on the results of the final project that has been carried out and the conclusions obtained, the suggestions for further research are as follows:

1. To design a water level system, better components can be used, the water level used does not work effectively because when the water has dropped, the remaining water is still attached to the water level surface which makes it difficult to analyze the water level status.

2. Using a better pump, because of the $5 \mathrm{~V}$ pump on the market, the quality of the pump's performance easily decreases so that the value of the water released is often inconsistent. For pumps, you can use a $12 \mathrm{~V}$ pump which is more stable and can release more water.

3. In terms of monitoring views made by MS. Visual Studio still looks simple, the system and monitoring can also be developed with a wireless system and thingspeak so that it can be monitored remotely.

\section{REFERENCES}

[1] Priya, S. J., Akshaya, S., Aruna, E., Julie, J. A. M., \& Ranjani, V. (2017). Flood monitoring and alerting system. Int. J. Comput. Eng. Technol, 8, 1-5.

[2] Singh G, Bisht N, Bisht P, Singh P. Iot Based Flood Monitoring and Alerting System with Weather Forecasting. Int J Innov Technol Explor Eng. 2020

[3] Arrahman, A. (2019). TA: Rancang Bangun Pengontrol Pintu Air Menggunakan Metode Fuzzy Berdasarkan Perubahan Ketinggian Air (Doctoral dissertation, Institut Bisnis dan Informatika Stikom Surabaya).

[4] Getu, B. N., \& Attia, H. A. (2016, December). Automatic water level sensor and controller system. In 2016 5th International Conference on Electronic Devices, Systems and Applications (ICEDSA) (pp. 1-4). IEEE.

[5] Das, S., Choudhury, A., Ghosh, S., Sarkar, S., Goswami, S., \& Ganguly, R. (2017). Automated Water-Level Detecting Pump Controller-Cum-Water Quality Analysis System.

[6] Okhaifoh, J. E., Igbinoba, C. K., \& Eriaganoma, K. O. (2016). Microcontroller based automatic control for water pumping machine with water level indicators using ultrasonic sensor. Nigerian Journal of Technology, 35(3), 579-583.

[7] Tobing, D. M. L., Kurniasih, J., \& Tetik, Y. N. (2019, November). The Prototype of Decision Support System For Selecting The Lands of Crops. In 2019 4th International Conference on Information Technology, Information Systems and Electrical Engineering (ICITISEE) (pp. 276-280). IEEE

[8] OKTAFIANSYAH, T. (2019). EVALUASI KAPASITAS DEBIT POMPA PADA RUMAH POMPA RAWA KEPA TERHADAP WADUK RAWA KEPA SEBAGAI PENGENDALI BANJIR (Doctoral dissertation, Universitas Mercu Buana Jakarta).

[9] Maulana, A., \& Bagiono, B. J. (2020). SISTEM INFORMASI JASA LAUNDRY KILOAN MENGGUNAKAN PROGRAM VISUAL STUDIO 2010. Jurnal Visualika, 6(2), 84-93.

[10] Pratama, B., Sfenrianto, S., Fajar, A. N., Amyus, A., \& Nurbadi, R. (2018, November). A Smart Agriculture Systems Based on Service Oriented Architecture. In 2018 3rd 
International Conference on Information Technology, Information System and Electrical Engineering (ICITISEE) (pp. 281-286). IEEE.

[11] Camburn, B., Viswanathan, V., Linsey, J., Anderson, D., Jensen, D., Crawford, R., ... \& Wood, K. (2017). Design prototyping methods: state of the art in strategies, techniques, and guidelines. Design Science, 3.

[12] Desnanjaya, I. G. M. N., Sastrawan, I. G. P., \& Pranata, I. W. D. (2020). SISTEM PERINGATAN KETINGGIAN AIR DAN KENDALI TEMUKU (PINTU AIR) UNTUK IRIGASI SAWAH. Jurnal RESISTOR (Rekayasa Sistem Komputer), 3(1), 112.

[13] ABDUL, N. I. N. B. (2018) FLOOD WATER LEVEL DETECTION FOR STUDENT NOTIFICATION.

[14] Al Rasyid, M. U. H., Kusumaningtyas, E. M., \& Setiawan, F. (2016, November). Application to determine water volume for agriculture based on temperature \& humidity using wireless sensor network. In 2016 International Conference on Knowledge Creation and Intelligent Computing (KCIC) (pp. 105-112). IEEE.

[15] Hrihorenko, I., Drozdova, T., Hrihorenko, S., \& Tverytnykova, E. (2019). Application of user interface Fuzzy Logic Toolbox for quality control of products and services. Advanced Information Systems, 3(4), 118-125.

[16] Harahap, S. (2020). MONITOR PADA KOMPUTER (HADRWARE).

[17] Riandika, P., Wigraha, N. A., \& Nugraha, I. N. P. (2018). Pengaruh Kecepatan Aliran Fluida Terhadap Capaian Suhu Optimal Hasil Rancangan Coolbox Zero Pollution. Jurnal Pendidikan Teknik Mesin Undiksha, 6(3), 160-167.

[18] Pane, F. F., Hikmarika, H., Dwijayanti, S., Yusup, M., \& Suprapto, B. Y. (2019). SISTEM PENGENDALIAN WATER PUMP UNTUK MENGATUR TINGGI LEVEL AIR DENGAN ALGORITMA PID PADA PLANT WATER TREATMENT. Prosiding Applicable Innovation of Engineering and Science Research, 2019, 336-341.

[19] Mappa, A., \& Jamlean, A. (2019). RANCANG BANGUN SISTEM KENDALI DAN MONITORING LEVEL, DEBIT AIR DAN PROTEKSI POMPA LISTRIK. Electro Luceat, 5(1), 5-15.

[20] Bai, Y. (2020). Data Updating and Deleting with Visual Basic. NET.

[21] Bai, Y. (2020). Data Selection Query with Visual Basic. NET.

[22] Davydov, R. V., Antonov, V. I., \& Molodtsov, D. V. (2018, December). Computer implementation of the mathematical model for water flow management by a hydro complex. In Journal of Physics: Conference Series (Vol. 1135, No. 1, p. 012088). IOP Publishing.

[23] Africa, A. (2017). A rough set based solar powered flood water purification system with a fuzzy logic model. ARPN Journal of Engineering and Applied Sciences, 12(3), 638647.

[24] OKTAFIANSYAH, T. (2019). EVALUASI KAPASITAS DEBIT POMPA PADA RUMAH POMPA RAWA KEPA TERHADAP WADUK RAWA KEPA SEBAGAI PENGENDALI BANJIR (Doctoral dissertation, Universitas Mercu Buana Jakarta).

[25] Rochani I., Bono, Suwoto G (2007). Rancang Bangun Pendeteksian Dini Banjir Berbasis Telemetri Di Daerah Sampangan Semarang Akibat Luapan Sungai Kaligarang. 